\title{
EFFICIENCY IN THE USE OF PHOSPHORUS BY COWPEA GENOTYPES
}

\author{
EFICIÊNCIA DO USO DE FÓSFORO POR GENÓTIPOS DE CAUPI
}

\author{
Idaiane Costa Fonseca ALMEIDA ${ }^{1}$; Leilson Costa GRANGEIRO²; Fábio Henrique Tavares \\ OLIVEIRA $^{2}$; Valdívia De Fátima Lima SOUSA ${ }^{1}$; Matheus Freitas SOUZA ${ }^{3}$ \\ 1. Pós-graduanda em Fitotecnia, Universidade Federal Rural do Semi-Árido, Mossoró, RN, Brasil, 2. Professor Associado do Centro de \\ Ciências Agrárias, Universidade Federal Rural do Semi-Árido, Mossoró, RN, Brasil. leilson@ufersa.edu.br; 3. Pós-graduando em \\ Fitotecnia, Universidade Federal Rural do Semi-Árido, Mossoró, RN, Brasil.
}

\begin{abstract}
Cowpea (Vigna unguiculata (L.) Walp.) is an edible legume with good ability to fix nitrogen and not demanding soil fertility. However, some genotypes may have a greater ability to utilize the nutrients available in the soil for their growth. Thus, the objective of this work was to evaluate the efficiency of phosphorus $(\mathrm{P})$ use in genotypes of cowpea. The experiment was conducted in the field and the experimental design was a randomized complete block design with four replicates arranged in a 2 x 5 factorial scheme. The treatments consisted of two $\mathrm{P}$ doses $\left(0\right.$ and $60 \mathrm{~kg} \mathrm{ha}^{-1}$ of $\left.\mathrm{P}_{2} \mathrm{O}_{5}\right)$ and five bean genotypes (Paulistinha, BRS Xiquexique, Pingo de Ouro, Corujinha, and Costela de Vaca). Each plot was formed by four plant rows, measuring $3.0 \mathrm{~m}$ in length, spaced $1.0 \times 0.3 \mathrm{~m}$, and with two plants per hole. The genotypes responded significantly to the increase in $\mathrm{P}$ levels in the soil, with increases in the number of seeds per pod, number of pods per plant, productivity, dry mass, and plant $\mathrm{P}$ accumulation. "BRS Xiquexique" was efficient and responsive, and it could be indicated as the most appropriate for cultivation in the region. "Corujinha" is the most suitable cultivar for production in high levels of $\mathrm{P}$ among the creole genotypes evaluated. "Costela de Vaca" and "Paulistinha" can be indicated for low P production in the soil.
\end{abstract}

KEYWORDS: Vigna unguiculata. Plant nutrition. Productivity. Agronomic efficiency.

\section{INTRODUCTION}

Cowpea (Vigna unguiculata (L.) Walp.) represents $37 \%$ of the planted area and $14 \%$ of the bean production in Brazil. In 2015, 452.000 tons were produced in an area of approximately 1.1 million hectares in the Brazil. In the North and Northeast, cowpea has great socioeconomic importance, because besides generating employment and income, it is a rich food source of protein, minerals, and fibers for the population.

The rusticity and precocity of cowpea make it adapt to a wide range of climate and soil, and it can be grown in practically all Brazilian regions. In the Northeast, cowpea is cultivated in monoculture or intercropped with maize and cassava, using several genotypes from selections made by local farmers, which have immeasurable genetic variability. This variability allows farmers to select genotypes adapted to their agroecological and socioeconomic conditions (FREIRE FILHO et al., 2005).

Phosphorus (P) is the macronutrient absorbed in less quantity by cowpea, but it is what most limits its production. The application of $\mathrm{P}$ stimulates growth, initiates nodule formation, and influences the efficiency of rhizobium-legume symbiosis (HARUANA; ALIYU, 2011). It is required in large quantities in young cells, such as shoot and root tips, where metabolism is high and cell division is rapid. It also aids flower initiation and seed and fruit development (NDAKEMI; DAKARA, 2007). Increases in shoot dry mass, number of pods, and grain mass directly influence bean productivity (YAMADA; ABDALLA, 2003).

Several authors have reported significant increases in cowpea productivity due to phosphate fertilization (LANA et al., 2006; TORQUATO et al., 2011, HARUANA; USMAN, 2013, COUTINHO et al., 2014). However, the response was differentiated among the genotypes, confirming there is an intraspecific variability in the capacity of absorption and utilization of this nutrient.

According to O'Toole and Bland (1987), the differentiated ability to absorb and use $\mathrm{P}$ among genotypes can be caused by the morphology of the root system; relation of root: aerial part, distribution, architecture, and root (ARÁUJO et al., 2012); and the efficiency of symbiosis with mycorrhizae. The selection of cowpea genotypes that present greater efficiency in the absorption and utilization of $\mathrm{P}$ constitutes an alternative for the cultivations carried out in soils of low availability of this nutrient.

Plant $\mathrm{P}$ efficiency has been defined in several ways. The efficiency of absorption is usually related to the ability to acquire maxima 1 amounts of 
$\mathrm{P}$ for minimal investment in root growth, and the efficiency of utilization is the relative ability to produce biomass for each unit of $\mathrm{P}$ accumulated (ELLIOTT; LAUCHLI, 1985). Efficiency must consider the amount of nutrient supply, and attempts to select bean genotypes tolerant of low $\mathrm{P}$ are likely to be affected by the symbiosis that such plants can establish with rhizobia.

In this context, the objective of this study was to evaluate the efficiency of $\mathrm{P}$ use in cowpea genotypes.

\section{MATERIAL AND METHODS}

The experiment was performed from April to July 2015 at the Experimental Farm Rafael Fernandes $\left(5^{\circ} 03^{\prime} 37^{\prime \prime} \mathrm{S}\right.$ and $37^{\circ} 23^{\prime} 50^{\prime \prime} \mathrm{W}$ and altitude of $72 \mathrm{~m}$ ), which belongs to the Universidade Federal Rural do Semi-Árido, in Mossoró, Rio Grande do Norte state, Brazil. The soil of the experimental area was classified as Red Yellow Argisol (EMBRAPA, 2006), with the following characteristics on the 0 to $20 \mathrm{~cm}$ layer: $\mathrm{pH}\left(\mathrm{H}_{2} \mathrm{O}\right)$ 5.1; $\mathrm{P}_{\text {(Mehlich) }}=2.5 \mathrm{mg} \mathrm{dm}^{-3} ; \mathrm{K}^{+}=68.7 \mathrm{mg} \mathrm{dm}^{-3} ; \mathrm{Na}^{+}$ $=5.8 \mathrm{mg} \mathrm{dm}^{-3} ; \mathrm{Ca}^{2+}=0.56 \mathrm{cmol}_{\mathrm{c}} \mathrm{dm}^{-3} ; \mathrm{Mg}^{2+}=0.90$ $\mathrm{cmol}_{\mathrm{c}} \mathrm{dm}^{-3} ; \mathrm{Al}^{3+}=0.80 \mathrm{cmol}_{\mathrm{c}} \mathrm{dm}^{-3} ; \mathrm{H}^{+}+\mathrm{Al}^{3+}=1.32$ $\mathrm{cmol}_{\mathrm{c}} \mathrm{dm}^{-3}$; organic matter $=2.43 \mathrm{~g} \mathrm{~kg}^{-1}$; sand $=910$ $\mathrm{g} \mathrm{kg}^{-1}$; silt $=20 \mathrm{~g} \mathrm{~kg}^{-1}$; and clay $=70 \mathrm{~g} \mathrm{~kg}^{-1}$.

The experimental design was a randomized complete block with four replications. The treatments were arranged in a factorial $2 \times 5$, with the first factor consisting of two doses of $\mathrm{P}(0$ and $60 \mathrm{~kg} \mathrm{ha}^{-1}$ of $\mathrm{P}_{2} \mathrm{O}_{5}$ ), and the second factor five genotypes of cowpea (Paulistinha, BRS Xiquexique, Pingo de Ouro, Corujinha, and Costela de Vaca). Each experimental unit consisted of four rows of plants, with a space of $1.0 \mathrm{~m}$ between the rows and $0.3 \mathrm{~m}$ among the plants. The total area was $12 \mathrm{~m}^{2}$. As a useful area, the two central rows of plants were used, totaling an area of $6.0 \mathrm{~m}^{2}$.

The doses of $\mathrm{P}$ were used to evaluate its efficiency of use by cowpea genotypes, where the dose "0" corresponded to the natural $\mathrm{P}$ content of the soil and $60 \mathrm{~kg} \mathrm{ha}^{-1}$ of $\mathrm{P}_{2} \mathrm{O}_{5}$, cowpea according to Lopes et al. (1998) in soil with low P content.

Cowpea genotypes were obtained from the seed bank of the Empresa de Pesquisa Agropecuária do Rio Grande do Norte (EMPARN) and were selected among the most cultivated by the producers in the different regions of the state of Rio Grande do Norte. The exception was the "BRS Xiquexique," which is a commercial cultivar developed by the Empresa Brasileira de Pesquisa Agropecuária (EMBRAPA).
Fertilization was carried out based on soil analysis and the recommendation of Cavalcanti (2008), placing in the planting furrow $13.5 \mathrm{kgha}^{-1} \mathrm{~N}$; $60 \mathrm{~kg} \mathrm{ha}^{-1} \mathrm{P}_{2} \mathrm{O}_{5}$ (treatments with $\mathrm{P}$ ); $20 \mathrm{kgha}^{-1} \mathrm{~K}_{2} \mathrm{O}$; $1.0 \mathrm{kgha}^{-1} \mathrm{~B}$; and $1.0 \mathrm{kgha}^{-1} \mathrm{Zn}$. In cover, $18.3 \mathrm{kgha}^{-}$ ${ }^{1} \mathrm{~N}$ and $20 \mathrm{kgha}^{-1} \mathrm{~K}_{2} \mathrm{O}$ were applied at 28 days after sowing (DAS). A drip irrigation system was used, with emitters spaced $0.3 \mathrm{~m}$ and flow $1.4 \mathrm{Lh}^{-1}$. The irrigations were carried out on intercalated days, applying $227.06 \mathrm{~mm}$ during all the cycle.

Harvesting was performed manually when the pods were completely dry. The following agronomic characteristics were evaluated: number of pods per plant (NPP), number of grains per pod (NGP), weight of 100 grains (P100), yield, dry matter of plant (DM), and $\mathrm{P}$ accumulation (AP). NPP, NGP. and DM were determined on five plants harvested in the plot area. After harvesting the grains, the plants (vegetative and reproductive organs) were oven-dried at $65^{\circ} \mathrm{C}$ until reaching constant weight to determine MSP. Subsequently, a sample of 100 grains was removed from each treatment and dried to $13 \%$ moisture to determine P100. Yield $\left(\mathrm{kg} \mathrm{ha}^{-1}\right)$ was estimated by harvesting all pods in the plot area. The harvested grains were weighed and the productivity (PROD) was estimated in $\mathrm{kg} \mathrm{ha}^{-1}$. The accumulation of $\mathrm{P}$ was determined in the different parts of the plant (vegetative and reproductive parts). The AP in the different parts of the plant was estimated by multiplying the nutrient contents $\left(\mathrm{g} \mathrm{kg}^{-1}\right)$ found by the dry matter values of the vegetative and reproductive organs.

Data were submitted to analysis of variance using the SISVAR statistical program (FERREIRA, 2011), and the means comparison was performed using the Tukey test at $5 \%$ probability.

The classification of the genotypes regarding the use efficiency and response to the application of $\mathrm{P}$ was carried out according to the methodology proposed by Fageria and Kluthcouski (1980). A chart represented the classification of the genotypes in a Cartesian plane.

\section{RESULTS AND DISCUSSION}

There was a significant interaction effect (genotypes and fertilization with $\mathrm{P}$ ) for all variables evaluated.

The genotypes "Pingo de Ouro," "Corujinha," and "Costela de Vaca" presented higher P100 compared to the "BRS Xiquexique" and "Paulistinha" genotypes when cultivated without the application of $\mathrm{P}$. In treatments with $\mathrm{P}$ fertilization, the genotypes "Pingo de Ouro" and "Corujinha" had 
higher P100 (Table 1). The variation in the mass of 100 grains among the genotypes was similar to that found by Freire et al. (2011) for local and improved cultivars of cowpea (15 to $25 \mathrm{~g}$ for each 100 grains). $\mathrm{P}$ fertilization did not alter the P100 in the genotypes "BRS Xiquexique," "Paulistinha," and "Corujinha" (Table 1). The weight of the grains is probably a qualitative character controlled by few genes and little influenced by the environment (RAMALHO et al., 1993). Similar results were found by Zucareli et al. (2011), who did not find a change in the dry matter of the seeds when applying $\mathrm{P}$ doses in the soil.

The genotypes "Paulistinha" and "BRS Xiquexique" produced a larger number of grains per pod compared to the other genotypes without the application of $\mathrm{P}$; however, when $\mathrm{P}$ was applied, all genotypes presented the same grain yield per pod. Fertilization with P did not change the NPP, except in the "BRS Xiquexique" genotype (Table 1). The highest NGP is a characteristic of high heritability and with high potential for increased productivity in breeding programs (VERBREE et al., 2015). The cultivar "BRS Xiquexique" has been shown to be able to produce a larger quantity of grains per pod even without the application of P. Thus, this cultivar can be used as a parent to increase the productivity of progenitors that do not have such a characteristic.

Table 1. Weight of 100 grains and number of grains per pod of cowpea genotypes, under low and high levels of phosphorus.

\begin{tabular}{|c|c|c|c|c|c|}
\hline \multirow[b]{2}{*}{ Genotypes } & \multicolumn{2}{|c|}{ Weight of 100 grains (g) } & \multicolumn{3}{|c|}{ Number of grains per pod } \\
\hline & $\begin{array}{l}0.0 \\
\left(\mathrm{~kg} \mathrm{ha}^{-1} \text { de } \mathrm{P}_{2} \mathrm{O}_{5}\right)\end{array}$ & $\begin{array}{l}60 \\
\left(\mathrm{~kg} \quad \mathrm{ha}^{-1} \text { de }\right. \\
\left.\mathrm{P}_{2} \mathrm{O}_{5}\right)\end{array}$ & $\begin{array}{l}0.0 \\
(\mathrm{~kg} \\
\left.\mathrm{P}_{2} \mathrm{O}_{5}\right)\end{array}$ & $\mathrm{ha}^{-1} \mathrm{de}$ & $\left(\mathrm{kg} \mathrm{ha}^{-1} \mathrm{de} \mathrm{P}_{2} \mathrm{O}_{5}\right)$ \\
\hline Paulistinha & $22.6 \mathrm{bA}$ & $23.9 \mathrm{abA}$ & & $12.9 \mathrm{abB}$ & $14.6 \mathrm{aA}$ \\
\hline BRS Xiquexique & $17.9 \mathrm{cA}$ & $16.3 \mathrm{cA}$ & & $14.0 \mathrm{aA}$ & $14.2 \mathrm{aA}$ \\
\hline Pingo de ouro & $24.3 \mathrm{abA}$ & $22.1 \mathrm{bA}$ & & $11.9 \mathrm{bB}$ & $13.8 \mathrm{aA}$ \\
\hline Corujinha & $24.7 \mathrm{abA}$ & 25.7 Aa & & $9.3 \mathrm{cB}$ & $15.2 \mathrm{aA}$ \\
\hline Costela de vaca & $25.1 \mathrm{aA}$ & $22.8 \mathrm{bA}$ & & $12.2 \mathrm{bB}$ & $13.6 \mathrm{aA}$ \\
\hline $\mathrm{CV}(\%)$ & 5.2 & & 6.2 & & \\
\hline Mean & 22.9 & 22.3 & & 12.1 & 14.3 \\
\hline
\end{tabular}

*Means followed by the same capital letter in the column and upper case in the line do not differ significantly at 5\% probability, by the Tukey test.

The NGP increased in all the genotypes tested due to fertilization with $\mathrm{P}$ (Table 2). When grown with $60 \mathrm{~kg}$ of $\mathrm{P}$, "BRS Xiquexique" produced higher NPP compared to the other genotypes (Table 2). In low $P$ disponibility, the cultivars produced few pods per plant and did not differ statistically (Table 2). Other studies have found an increase in the number of pods in cowpea varieties (OLIVEIRA et al., 2011; COUTINHO et al., 2014; NKAA et al., 2014).

P fertilization in soil stimulates root growth in cowpea plants, favoring the formation of new leaves and consequently fruit formation (COUTINHO et al., 2014). According to Viana et al. (2011), the NPP is the primary component that most correlates with grain yield and is strongly influenced by environmental conditions.

The yield under low $\mathrm{P}\left(0.0 \mathrm{~kg} \mathrm{ha}^{-1}\right.$ of $\left.\mathrm{P}_{2} \mathrm{O}_{5}\right)$ was not different among genotypes. However, when $60 \mathrm{~kg} \mathrm{ha}^{-1}$ of $\mathrm{P}_{2} \mathrm{O}_{5}$ was applied, the genotypes "Corujinha" and "BRS Xiquexique" were superior to the others (Table 2). The increase in yield of cowpea genotypes was mainly due to the increase in the NGP and NPP from the application of P.

Fertilization with $\mathrm{P}$ increased dry matter yield in all cowpea genotypes (Table 3). The genotypes "Corujinha" and "Costela de Vaca" produced a greater amount of dry matter compared to the other genotypes (Table 3). Oliveira et al. (2011), Araújo et al. (2012), and Namayanja et al. (2014) found similar results with other cowpea cultivars. "BRS Xiquexique" presented lower dry matter accumulation compared to the other genotypes (Table 3). This fact demonstrates the genetic variability of the cultivars tested when applying $\mathrm{P}$ doses in the soil. The genotype "BRS Xiquexique" destined the photoassimilates synthesized in the leaves to the reproductive organs, increasing the grain production. This characteristic is important for cultivars of high productivity, and thus, the genotype "BRS Xiquexique" can be a source of favorable alleles for other cultivars that do 
not have this characteristic (ALMEIDA et al., 2017;

HIRASAWA et al., 2017).

Table 2. Number of pots per plant and yield of cowpea genotypes, under low and high levels of phosphorus.

\begin{tabular}{|c|c|c|c|c|}
\hline \multirow[b]{2}{*}{ Genotypes } & \multicolumn{2}{|c|}{ Number of pots per plant } & \multicolumn{2}{|l|}{ Yield $\left(\mathrm{kg} \mathrm{ha}^{-1}\right)$} \\
\hline & $\begin{array}{l}0.0 \\
\left(\mathrm{~kg} \mathrm{ha}^{-1} \text { de } \mathrm{P}_{2} \mathrm{O}_{5}\right)\end{array}$ & $\begin{array}{l}60 \\
(\mathrm{~kg} \\
\left.\mathrm{P}_{2} \mathrm{O}_{5}\right)\end{array} \mathrm{ha}^{-1} \quad \mathrm{de}$ & $\begin{array}{l}0.0 \\
(\mathrm{~kg} \\
\left.\mathrm{P}_{2} \mathrm{O}_{5}\right)\end{array} \mathrm{ha}^{-1} \quad \mathrm{de}$ & $\begin{array}{l}60 \\
\left(\mathrm{~kg} \mathrm{ha}^{-1} \text { de } \mathrm{P}_{2} \mathrm{O}_{5}\right)\end{array}$ \\
\hline Paulistinha & $1.62 \mathrm{aB}$ & $8.82 \mathrm{bA}$ & $315.15 \mathrm{aA}$ & $1115.14 \mathrm{bcA}$ \\
\hline BRS Xiquexique & $2.55 \mathrm{aB}$ & $12.92 \mathrm{aA}$ & $362.01 \mathrm{aB}$ & $1444.90 \mathrm{abA}$ \\
\hline Pingo de ouro & $1.35 \mathrm{aB}$ & $4.07 \mathrm{cA}$ & $170.39 \mathrm{bB}$ & $907.63 \mathrm{cA}$ \\
\hline Corujinha & $1.72 \mathrm{aB}$ & $8.52 \mathrm{bA}$ & $239.51 \mathrm{bB}$ & $1536.71 \mathrm{aA}$ \\
\hline Costela de vaca & $1.55 \mathrm{aB}$ & $6.30 \mathrm{bcA}$ & $362.64 \mathrm{aB}$ & $1200.39 \mathrm{bcA}$ \\
\hline $\mathrm{CV}(\%)$ & 24.8 & & 21.1 & \\
\hline Means & 1.76 & 8.13 & 289.94 & 1240.95 \\
\hline
\end{tabular}

*Means followed by the same capital letter in the column and upper case in the line do not differ significantly at 5\% probability, by the Tukey test.

Table 3. Dry matter and phosphorus accumulation of cowpea genotypes, under low and high levels of phosphorus.

\begin{tabular}{|c|c|c|c|c|c|}
\hline \multirow[b]{2}{*}{ Genotypes } & \multicolumn{2}{|c|}{ Dry matter $\left(\mathrm{kg} \mathrm{ha}^{-1}\right)$} & $\begin{array}{l}\text { Phosphorus } \\
\mathrm{ha}^{-1} \text { ) }\end{array}$ & accumulation (kg & \multirow[t]{2}{*}{ EPD } \\
\hline & $\begin{array}{l}0.0 \\
(\mathrm{~kg} \\
\left.\mathrm{P}_{2} \mathrm{O}_{5}\right)\end{array}$ & $\begin{array}{l}60 \\
\left(\mathrm{~kg} \mathrm{ha}^{-1} \text { de } \mathrm{P}_{2} \mathrm{O}_{5}\right)\end{array}$ & $\begin{array}{l}0.0 \\
\left(\mathrm{~kg} \mathrm{ha}^{-1} \text { de }\right. \\
\left.\mathrm{P}_{2} \mathrm{O}_{5}\right)\end{array}$ & $\begin{array}{l}60 \\
\left(\mathrm{~kg} \mathrm{ha}^{-1} \text { de }\right. \\
\left.\mathrm{P}_{2} \mathrm{O}_{5}\right)\end{array}$ & \\
\hline Paulistinha & $3035.68 \mathrm{aB}$ & $3579.63 \mathrm{cdA}$ & $10.92 \mathrm{aB}$ & $14.76 \mathrm{cA}$ & $13.33 \mathrm{ab}$ \\
\hline $\begin{array}{l}\text { BRS } \\
\text { Xiquexique }\end{array}$ & $2300.09 \mathrm{bB}$ & $3381.43 \mathrm{dA}$ & $8.83 \mathrm{aB}$ & $21.11 \mathrm{aA}$ & $18.05 \mathrm{ab}$ \\
\hline Pingo de ouro & $2627.26 \mathrm{abB}$ & $4045.02 \mathrm{bcA}$ & $9.28 \mathrm{aB}$ & $17.88 \mathrm{bA}$ & $12.29 \mathrm{~b}$ \\
\hline Corujinha & $2753.68 \mathrm{abB}$ & $4565.02 \mathrm{abA}$ & $8.84 \mathrm{aB}$ & $13.23 \mathrm{cA}$ & $21.62 \mathrm{a}$ \\
\hline Costela de vaca & $2906.40 \mathrm{aB}$ & $4993.36 \mathrm{aA}$ & $4.78 \mathrm{bB}$ & $18.74 \mathrm{abA}$ & $13.96 \mathrm{ab}$ \\
\hline $\mathrm{CV}(\%)$ & 8.2 & & 9.4 & & 25.3 \\
\hline Means & 2724.62 & 4112.89 & 8.53 & 17.14 & 15.85 \\
\hline
\end{tabular}

*Means followed by the same capital letter in the column and upper case in the line do not differ significantly at 5\% probability, by the Tukey test.

The genotypes responded to fertilization of $\mathrm{P}_{2} \mathrm{O}_{5}$ in the soil, accumulating a greater amount of $\mathrm{P}$ in their tissues (Table 3). "BRS Xiquexique" and "Costela de Vaca" accumulated higher amounts of $\mathrm{P}$ than others genotypes when $\mathrm{P}$ doses were applied to the soil (Table 3). However, when P doses were not added to the soil, the genotype "Costela de Vaca" had the lowest $P$ accumulation (Table 3).

The ability of cowpea plants to accumulate $\mathrm{P}$ in their tissues depends on the availability and ability of the genotype to extract the nutrient from the soil (KUGLENU et al., 2014; ALMEIDA et al., 2017). "Costela de Vaca" did not have the same capacity to accumulate $\mathrm{P}$ under conditions of restriction of this nutrient, so probably this cultivar is not able to extract greater amount of $\mathrm{P}$ bound to the colloids of the soil. In crop rotation systems, succession between grass and legume species is highly beneficial to improve soil quality. However, it is necessary to choose species that have a positive effect on soil properties (EERD et al., 2014). Species that present higher capacity to accumulate nutrients may promote the cycling of less mobile nutrients in the soil, such as P (RUMPEL et al., 2015). Therefore the genotypes "BRS Xiquexique," "Paulistinha," "Pingo de Ouro," and "Corujinha" are preferred in crops in succession with other species. Other cultivars of cowpea, such as "BRS Tumucumaque" and "BRS Guariba," vary on 
average $23.01 \mathrm{~kg} \mathrm{ha}^{-1}$ of $\mathrm{P}$ accumulated (ARAÚJO et al., 2012).

The genotype "BRS Xiquexique" was classified as efficient and responsive (Figure 1). This behavior indicates that it has a greater capacity of resilience compared to the other genotypes, because it produced above average in conditions of low $\mathrm{P}$ level, and also responded positively to the application of $60 \mathrm{~kg}$ of $\mathrm{P}_{2} \mathrm{O}_{5}$ in the soil, increasing its productivity.

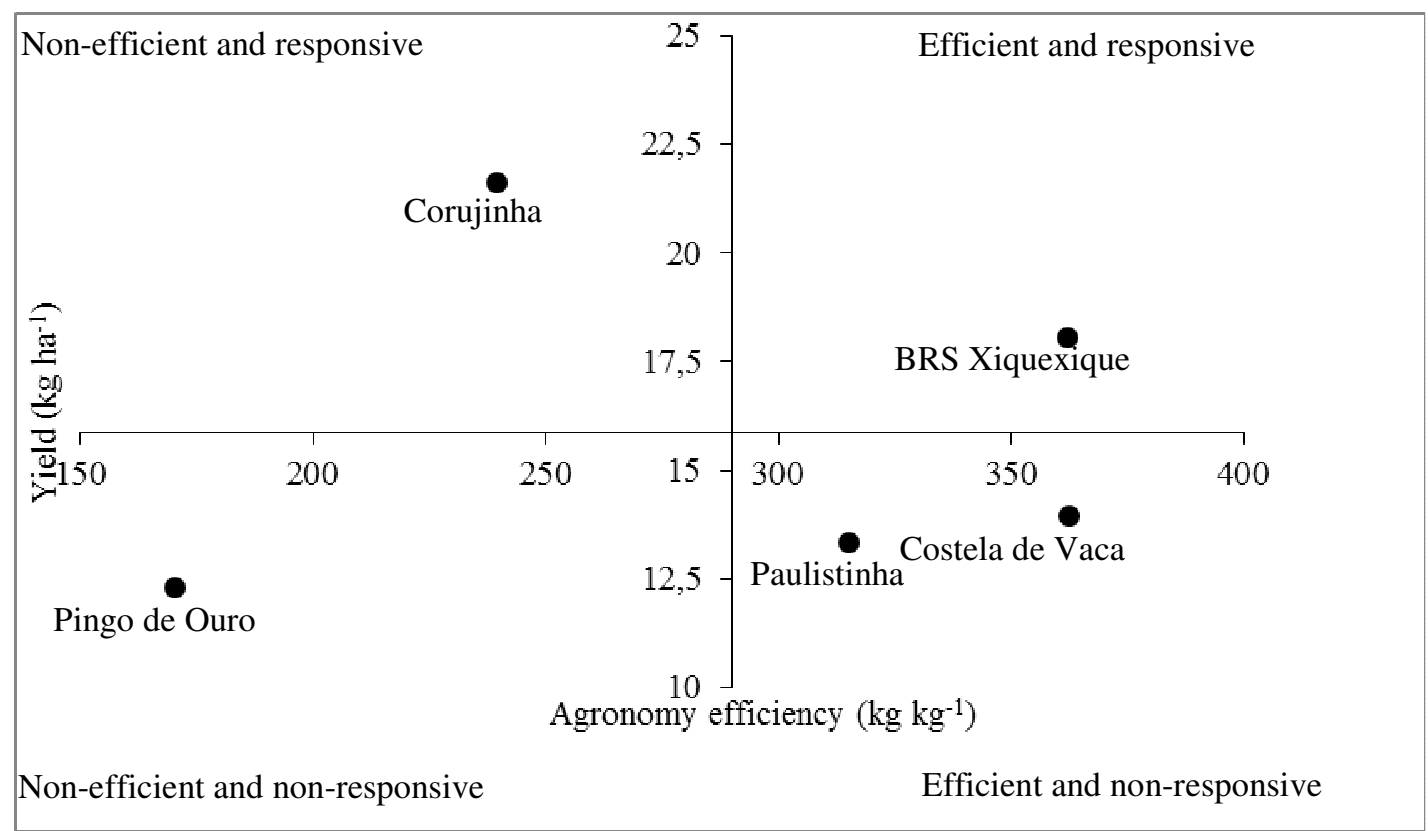

Figure 1. Classification of cowpea genotypes according to agronomic efficiency, yield response and dry matter.

The genotype "Corujinha" was classified as nonefficient and responsive (Figure 1). The productivity achieved was low under conditions of soil $\mathrm{P}$ restriction. However, this genotype obtained a considerable increase in productivity when a dose of 60 of $\mathrm{P}_{2} \mathrm{O}_{5}$ was applied to the soil, equating to the more productive genotypes. Despite low productivity in low soil $\mathrm{P}$ conditions, this cultivar was able to accumulate a quantity of $\mathrm{P}$ similar to "BRS Xiquexique"; thus, it can help the producer to increase the $\mathrm{P}$ cycling in soils with low natural availability.

The genotype "Pingo de Ouro" was classified as nonefficient and nonresponsive (Figure 1). The yield of the "Pingo de Ouro" cowpea was very low under conditions with restriction of $\mathrm{P}$, and even adding $60 \mathrm{~kg} \mathrm{P}_{2} \mathrm{O}_{5}$ this genotype was not able to increase grain yield.

The genotypes "Costela de Vaca" and "Paulistinha" were classified as efficient and nonresponsive (Figure 1). Unlike the genotype "Pingo de Ouro,"
"Costela de Vaca" and "Paulistinha" can be indicated for systems where there will be a restriction of $P$ in the soil, because they reached a productivity higher than the average productivity of the evaluated genotypes. However, for crops where $P$ rates will be applied to obtain a higher grain yield, these two genotypes should not be indicated due to the low response rate to the increase of this nutrient in the soil.

\section{CONCLUSION}

The genotypes responded differently to soil $\mathrm{P}$ levels. "BRS Xiquexique" was efficient and responsive, and it could be indicated as the most appropriate for cultivation in the region. "Corujinha" is the most suitable cultivar for production in high levels of $\mathrm{P}$ among the Creole genotypes evaluated. The genotypes "Costela de Vaca" and "Paulistinha" can be indicated for low P production.

RESUMO: O feijão-caupi (Vigna unguiculata (L.) Walp.) é uma leguminosa comestível com boa capacidade de fixar nitrogênio e pouco exigente em fertilidade do solo. No entanto, alguns genótipos podem apresentar uma maior capacidade em utilizar os nutrientes disponíveis no solo para seu crescimento. Assim, o objetivo deste trabalho foi avaliar a eficiência do uso de fósforo em genótipos de feijão-caupi. $\mathrm{O}$ experimento 
foi conduzido em campo, e o solo classificado como Argissolo Vermelho-Amarelo. O delineamento experimental utilizado foi em blocos casualizados, com quatro repetições, disposto em um esquema fatorial $2 \mathrm{x}$ 5. Os tratamentos foram constituídos pela combinação de duas doses de fósforo ( 0 e $\left.60 \mathrm{~kg} \mathrm{ha}^{-1} \mathrm{de}_{2} \mathrm{P}_{2} \mathrm{O}_{5}\right)$ e cinco genótipos de feijão-caupi (Paulistinha, BRS Xiquexique, Pingo de Ouro, Corujinha e Costela de Vaca). Cada parcela foi formada por quatro fileiras de planta, medindo $3,0 \mathrm{~m}$ de comprimento, espaçadas de 1,0 x $0,3 \mathrm{~m}$, com duas plantas por cova. Os genótipos responderam de forma significativa ao aumento do nível de fósforo no solo, com incrementos no número de sementes por vagem, número de vagens por planta, produtividade, massa seca e acúmulo de P da planta. O BRS Xiquexique foi eficiente e responsivo, podendo ser indicado como o mais apropriado para o cultivo na região. Corujinha é a cultivar mais indicada para produção em níveis alto de fósforo entre os genótipos crioulos avaliados. Os genótipos crioulos costela de Vaca e Paulistinha podem ser indicados para produção em baixo nível de fósforo.

PALAVRAS-CHAVE: Vigna unguiculata. Nutrição de planta. Produtividade. Eficiência agronômica

\section{REFERENCES}

ALMEIDA, F.S.; MINGOTTE, F.L.C.; LEMOS, L.B.; SANTANA, M.J. Agronomic performance of cowpea cultivars depending on sowing seasons in the cerrado biome. Revista Caatinga, v. 30, n. 2, p. 361-369, 2017. http://dx.doi.org/10.1590/1983-21252017

ARAUJO, E.O; SANTOS, E.F.; OLIVEIRA, G.Q.; CAMACHO, M.A.; DRECH, D.M. Nutritional eficiency of cowpea varieties in the absorption of phosphorus. Agronomia colombiana, v.30, n.3, p.419-429, 2012.

CAVALCANTI, F. J. Recomendações de adubação para o Estado de Pernambuco: $2^{\mathrm{a}}$ aproximação. 3 ed. Recife, PE: IPA. 2008. 212 p.

COUTINHO, P.W.R.; SILVA, D.M.S.; SALDANHA, E.C.M.; OKUMURA, R.S; SILVA JÚNIOR, M.L. Doses de fósforo na cultura do feijão-caupi na região nordeste do Estado do Pará. Revista Agro@mbiente, v. 8, n. 1, p. 66-73, 2014.

EERD, L.V.; CONGREVES, K.A.; HAYES, A.; VERHALLEN, A.; HOOKER, D.C. Long-term tillage and crop rotation effects on soil quality, organic carbon, and total nitrogen. Canadian Journal of Soil Science, v. 94, n. 3, p. 303-315, 2014. https://doi.org/10.4141/cjss2013-093

EMPRESA BRASILEIRA DE PESQUISA AGROPECUÁRIA - EMBRAPA. Sistema Brasileiro de Classificação de solos. 3.ed. Brasília: Embrapa Informação Tecnológica. 2006. 353p.

ELLIOTT, G.C; LÄUCHLI, A. Phosphorus efficiency and phosphate-iron interaction in maize. Agronomy Journal, Madison, v.77, n.2, p.399-403, 1985. http://dx.doi.org/10.2134/agronj1985.00021962007700030011x

FAGERIA, N. D.; KLUTHCOUSKI, J. Metodologia para avaliação de cultivares de arroz e feijão para condições adversas de solo. Brasília: Embrapa-CNPAF, 1980.

FERREIRA, D. F. SISVAR: A Computer statistical analysis system. Revista Ciência e Agrotecnologia, v. 35, n. 6, p. 1039-1042, 2011. http://dx.doi.org/10.1590/S1413-70542011000600001

FREIRE FILHO, F. R.; RIBEIRO, V. Q.; BARRETO, P. D.; SANTOS, A. A. Melhoramento genético. In: FREIRE FILHO, LIMA, J. A.; RIBEIRO, V. Q. (Eds.). Feijão-caupi: avanços tecnológicos. Brasília, DF: Embrapa Informações Tecnológicas, 2005.p. 29-92.

HARUANA, I. M.; ALIYU, L. Yield and economic returns of sesame (Sesamum indicum .L.) as influenced by poultry manure, nitrogen and phosphorus at Samaru. Elixir Agriculture, v.39, p.4884-4887, 2011. 
HARUANA, I.M.; USMAN, A. Agronomic efficiency of cowpea varieties (Vigna unguiculata (L.) Walp) under varying phosphorus rates in Lafia, Nassarawa state, Nigeria. Asian Journal of Crop Science, v.5, n.2, p.209-215, 2013. http://dx.doi.org/10.3923/ajcs.2013.209.215

HIRASAWA, T.; SATO, K.; YAMAGUCHI, M.; NARITA, R.; KODAMA, A.; ADACHI, S.; OOKAWA, T.; SATO, K. Differences in dry matter production, grain production, and photosynthetic rate in barley cultivars under long-term salinity. Plant Production Science, p. v. 20, n.3, p.1-12, 2017. https://doi.org/10.1080/1343943X.2017.1343647

KUGLENU, Y. O. ; KUMAGA, F.K.; OFORI, K. ; ADU-GYAMFI, J. J. Evolucion of cowpea genotypes for phosphorus use efficiency. Journal of Agricultural and Crop. Research. v.2, n.10, p. 202-210, 2014.

LANA, R. M. Q.; JÚNIOR, L. A. Z.; CORREIA, N. M.; LANA, A. M. Q. Variabilidade entre genótipos de feijoeiro na eficiência no uso do fósforo. Revista Ciência Rural, v.36, n.3, p.778-784, 2006.

http://dx.doi.org/10.1590/S0103-84782006000300009

NAMAYANJA, A.; SEMOKA, J.; BURUCHARA, R.; NCHIMBI, S.; WASWA, M. Genotypic variation for tolerance to low soil phosphorous in common bean under controlled screen house conditions. Agricultural Sciences, v.5, p. 270-285, 2014. http://dx.doi.org/10.4236/as.2014.54030

NDAKIDEMI, P.A.; DAKRA, F. D. Yield components of nodulated cowpea (Vigna unguiculata (L.) Walp) and maize (Zea mays) plants grown with exogenous phosphorus in different cropping systems. Australian Journal of Experimental Agriculture, v.47, p.587-590, 2007. http://dx.doi.org/10.1071/EA05274

NKAA, F.A; NWOKEOCHA, O.W.; IHUOMA, O. Effect of phophorus fertilizer on growth and yeild of cowpea. IOSR Journal of phamacy and Biological sciences, v. 9, n.5, p. 74-82, 2014. http://dx.doi.org/10.9790/3008-09547482

OLIVEIRA, G. A.; ARAÚJO, W. F.; CRUZ, P. L. S.; SILVA, W. L. M.; FERREIRA, G. B. Resposta do feijão-caupi as lâminas de irrigação e as doses de fósforo no cerrado de Roraima. Revista Ciência Agronômica, v. 42, n. 4, p. 872-882, 2011.

O'TOOLE, J.C.; BLAND, W.L. Genotypic variation in crop plant root systems. Advances in Agronomy, v.41, p.91-145, 1987. https://doi.org/10.1016/S0065-2113(08)60803-2

RAMALHO, M. A. P.; ABREU, A. F. B.; SANTOS, J. B. Desempenho de progênies precoces de feijoeiro (Phaseolus vulgaris L.) em diferentes locais e épocas de plantio. Revista Ceres, v. 40, n. 229, p. 272-280, 1993.

RUMPEL, C.; CRÈME, A.; NGO, P.T. VELÁSQUEZ, G.; MORA, M.L.; CHABBI, A. The impact of grassland management on biogeochemical cycles involving carbon, nitrogen and phosphorus. Journal of soil science and plant nutrition, v.15, n.2, p.353-371, 2015. http://dx.doi.org/10.4067/S0718-95162015005000034

TORQUATO; J.P; AQUINO, B.F.; SOUSA, G.G.; GUIMARÃES, F.V.A.; ANJOS, D. C. Teores de Ca, k, Mg e P na cultura do feijão-caupi sob diferentes doses de fósforo. Agropecuária Técnica, v.32, n.1.p 79-87, 2011. https://doi.org/10.25066/agrotec.v32i1.9068

VERBREE, D.A.; SINGH, B.B.; PAYNE, W.A. Genetics and Heritability of Shoot Drought Tolerance in Cowpea Seedlings. Crop Science, v. 55, n. 1, p. 146-153, 2015. https://doi.org/10.2135/cropsci2014.02.0137

VIANA, T. O.; VIEIRA, N. M. B.; MOREIRA, G. B. L.; BATISTA, R. O.; CARVALHO, S. J. P.; RODRIGUES, H. F. F. Adubação do feijoeiro cultivado no norte de Minas Gerais com nitrogênio e fósforo. Revista Ceres, v.58, p.115-120, 2011. http://dx.doi.org/10.1590/S0034-737X2011000100017 
YAMADA, T; ABDALLA, S. R. S. Simpósio destaca a essencialidade do fósforo na agricultura brasileira. Informações agronômicas, n. 102, p. 1-9, 2003.

ZUCARELI, C.; PRANDO, A. M.; RAMOS JUNIOR, E. U.; NAKAGAWA, J. Fósforo na produtividade e qualidade de sementes de feijão carioca precoce cultivado no período das águas. Revista Ciência Agronômica, v. 42 , n. 1, p. 32-38, 2011. 